\title{
愛媛大学大学院医学系研究科 老年・神経・総合診療内科学講座
}

\author{
大八木保政
}

（日老医誌 $2018 ； 55 ： 417-419 ）$

\section{講座の沿革}

当講座は, 1997 年 12 月に大阪大学老年内科の三木哲 郎先生を初代教授として老年医学講座として開設され, 1999 年 4 月に医学部附属病院に老年科が設置されまし た. 老年科とともに，当時愛媛大学には未設置であった 神経内科を担当するために，九州大学神経内科から野村 拓夫先生が助手に着任し，神経内科も開設しました。以 来，爱媛大学病院の老年科と神経内科を担当分野とする 臨床講座として発展してきました. その後, 名称が加齢 制御内科学講座に変わり，2013 年より現在の老年・神 経・総合診療内科学講座となっています。2014 年 3 月 に三木教授が退任し，2015 年 5 月に九州大学神経内科 より大八木保政が第二代教授として着任しました．現在 大学在籍の医局員は, 教授 1 名, 特任教授 1 名, 講師 1 名, 特任講師 1 名, 助教 3 名, 医員 (専攻医) 1 名の計 8 名です. 他に 3 5 名が連携病院に出向中です.

当講座の特色の一つとして 2006 年に病院内に開設し た「抗加齢センター」があり，2010 年に新施設に移り 「抗加齢・予防医療センター」と名称変更しました。主 に動脈硬化症研究のための抗加齢ドックを行っているア ンチエイジング研究の拠点です. 約 300 名/年の受検者 があり，現在までに 3,000 名を超える受検者の臨床デー 夕および遺伝子が蓄積しています.

\section{教 育}

卒前教育では, 3 年生の内科学の神経内科学領域講義, 4 年生の老年医学講義, 5 年生の導入型臨床実習 (ベッ ドサイド)，6 年生の参加型臨床実習 (クリニカルクラー
クシップ）を担当しています。入院患者のほとんどは神 経内科疾患であり, 多発性硬化症や炎症性ニューロパ チーなどの自己免疫疾患, パーキンソン病や筋萎縮性側 索硬化症などの神経変性疾患から, 脳卒中 ·認知症・て んかんなどのコモンな疾患の診療を経験します。6 年生 の実習では，もの忘れ外来の新患の診療なども一緒に経 験するようにしています，老年医学の立場からは，抗加 齢・予防医療センターの見学・実習も全員経験します. また，愛媛大学独自のカリキュラムに 1 年生から研究を 経験する「医科学研究」があり, 当講座では, 抗加齢・ 予防医療センターの統計学的研究, 血管超音波検査によ る臨床的研究, 培養細胞を用いた実験的研究まで, 幅広 い手法を経験する機会を提供しています。ささらに，研究 意欲が高い学生は 2 年生以降も医学部講義の合間に研究 活動を継続し，学部在学中に英語原著論文を複数発表す る学生も時々います.

卒後教育では, 愛媛大学病院の初期研修医は毎年 40 名程度で, そのほとんどは県内の連携病院とのたすき掛 けで研修し, 大学病院の研修期間に内科研修の一環で当 科にローテートしてきます。当科では神経疾患の入院患 者の診療研修が主体ですが，老年医学的見地から全人的 医療の教育を心掛けています。 3 年目以降の専門研修で は，老年病専門医と神経内科専門医の育成を担当してい ます。現在は専門医制度が大きく変わる過渡的時期です が，内科系の各講座と協力して，まず総合内科専門医を 育成することを目指しています。また，老年病専門医や 神経内科専門医の取得に必要な多様な症例経験は学会認 定の教育施設との連携研修でカバーし，同時に愛媛県の 地域医療にも大きく貢献しています.

愛媛大学大学院医学系研究科老年 - 神経 - 総合診療内科学講座

連絡責任者：大八木保政 愛媛大学大学院医学系研究科老年・神経・総合診療内科学〔テ791-0295 愛媛県東温市志津川] e-mail: ohyagiy@m.ehime-u.ac.jp doi: 10.3143 /geriatrics. 55.417 


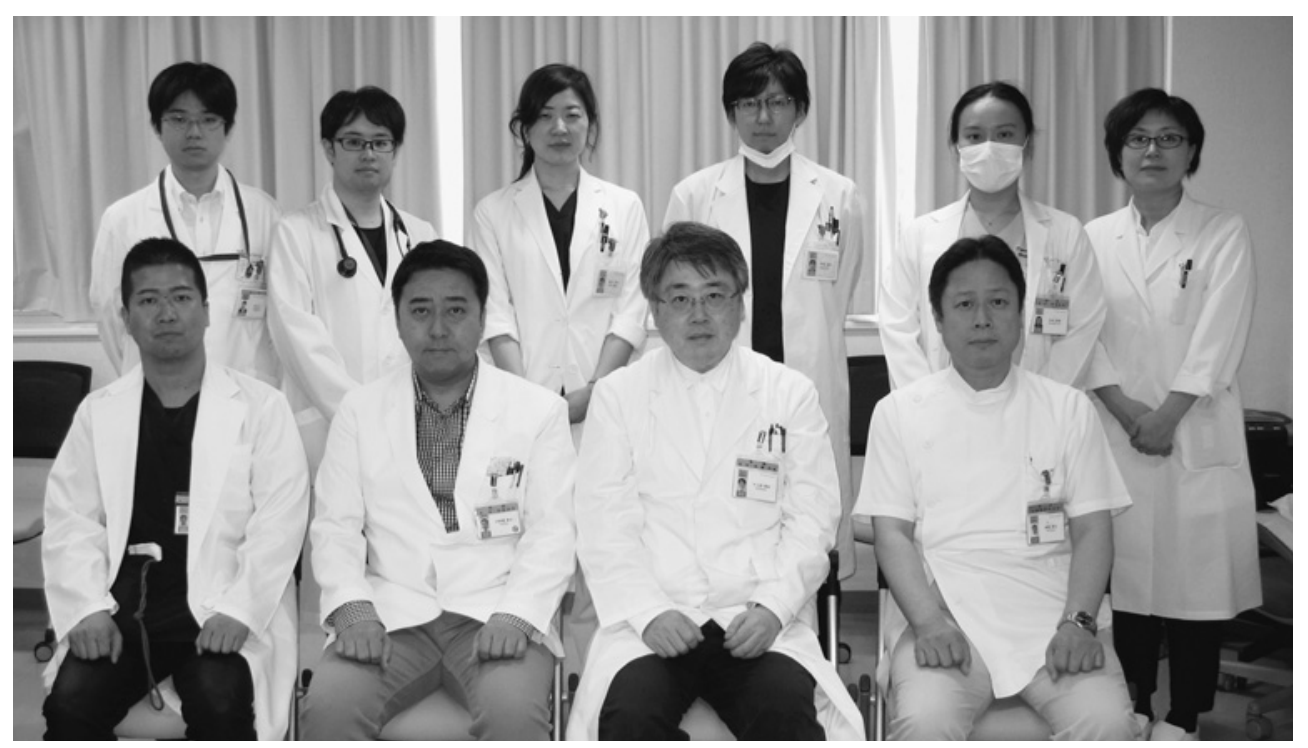

写真 前列左から, 越智雅之特任講師, 伊賀瀬特任教授, 大八木教授, 越智博文講師

\section{診 療}

当講座は老年内科と神経内科で病床は 10 床ですが, 入院患者のほとんどは神経内科疾患です.当科の特徵は, 多発性硬化症や視神経脊髄炎などの自己免疫性神経疾患 が 30\% 以上と多いこと, 爱媛大学病院は爱媛県認知症 疾患医療センターの基幹施設であり精神科と共同で認知 症診療に取り組んでいること, 同じく愛媛県難病医療セ ンターの基幹施設として地域連携の中核を担っているこ と, 脳外科と協力して脳卒中医療を担っていることなど が挙げられます。また, 大学病院に隣接する国立病院機 構愛媛医療センターに常勤の神経内科医 2 名を配し, 当 講座出身の神経難病専門の往診医と連携して, 診断・レ スパイト・在宅往診まで, 幅広く神経難病医療をカバー しています。老年内科としては, 循環器専門医の特任教 授が中心となって高血圧や動脈硬化症などの外来診療や 上記の抗加齢・予防医療センターの運営を担っていま す.

助教以上のスタッフは 7 名と少数ですが, それぞれが 老年病専門医, 神経内科専門医, 循環器専門医, 脳卒中 専門医, 認知症専門医, 総合内科専門医などダブル・ト リプルで専門医を持ち, 多種多様な疾患の診療や指導を 担っています。最近は, プライマリ・ケア認定医やリハ ビリ専門医などを目指す若手もおり, 各医局員の希望に 応じたキャリアプランを支援しています.

\section{研 究}

現在取り組んでいる主な研究を 4 つ紹介します.

\section{(1)抗加齢・予防医療センターにおける老年医学的研究}

長年, 動脈硬化症や高血圧など血管系の老化に関する 臨床疫学的な研究を行っていますが, 近年は, 軽度認知 障害 (MCI) の発症促進因子や予防の研究にも力を入れ ています。最近の知見として, 皮下組織の終末糖化産物 の蓄積量が MCI 診断に有用なこと, 愛媛県産柑橘類の 河内晚柑の果皮に豊富に含まれているオーラプテンが脳 の炎症を抑制し MCI 発症を防止する可能性などを報告 しました. 現在, 健康寿命の延伸や寝たきり防止を目標 としたサルコペニア・フレイルの研究も進めています.

\section{(2)アルツハイマー病（AD）の基礎的・臨床的研究}

近年, $\mathrm{AD}$ は「脳の糖尿病」あるいは「3 型糖尿病」 と言われるように, 脳の病態として糖インスリン代謝異 常が重要と考えられています。私たちは，AD マウスモ デルの記憶力を改善する薬剤の一つとしてアポモルフィ ンを同定し, アポモルフィンが脳神経細胞のインスリン 抵抗性を改善することを見出しました. さらに現在，ア ミロイド $\beta$ 蛋白によるインスリンシグナリング障害の 培養細胞実験系を作成し, 糖尿病治療薬とアポモルフィ ンの併用効果などを検討しています. また, アポモルフィ 
ン舌下錠の有効性を検討するための $\mathrm{AD}$ 患者を対象と する臨床研究を計画中です.

\section{(3)多発性硬化症（MS）の新規治療法の開発研究}

近年, MS の再発には T 細胞だけでなく, B 細胞の関 与が提唱されています。再発期 MS では Toll-like receptor 4 （TLR4）とCD40を介したシグナルで B 細胞から の IL-10 産生が増加し, 寛解が誘導されています。私た ちは, 京都大学との共同研究で, IL-10 産生制御性 B 細 胞を標的とする MS の新規免疫細胞療法の開発を目指 しています。

(4)血管超音波やホルター心電図などを用いた臨床的研究 血管超音波検査で $\mathrm{NO}$ や $\mathrm{CO}_{2}$ を介する血管の内皮機 能を解析する手法を使い, 特に免疫性神経疾患, 神経変 性疾患および認知症の患者における内皮機能障害を解析 しています。免疫性神経疾患の再発・寛解時や治療前後
の血管内皮機能を調べることで，各疾患における再発予 見・治療効果判定・進行度予測などへの応用を検討して います。また，入院中の神経疾患患者に対してホルター 心電図検査を行い, その変動から自律神経機能異常を解 析しています。一般に自律神経障害が目立たない疾患に おいても潜在的な自律神経機能異常が示唆される結果を 得ています。

\section{おわりに}

老年内科は高齢者に対して総合的・全人的な医療を目 標にしており, 領域横断的な診療科です。一方, 神経内 科は, 名称を脳神経内科へ変更して, さらに中枢神経を 重視する縦断的な専門領域への流れが進んでいます。そ の縦横を結ぶ全国的にも数少ない臨床系講座として, 総 合内科専門医 - 神経内科専門医 - 老年病専門医などの育 成を進めたいと思います。 